\title{
Securing Uniformity in National Law: A Proposal for National Stare Decisis in the Courts of Appeals
}

Conflict of decision among the federal courts of appeals has produced a lack of uniformity in national law. ${ }^{1}$ The "law of the circuit" rulethat the decision of one court of appeals is binding only within the circuit and need not be followed by district courts or courts of appeals outside the circuit-causes such conflict among the circuits. Although it has been thought that the Supreme Court would resolve intercircuit conflicts, ${ }^{2}$ the Court as a practical matter cannot hear and decide all cases containing an issue on which intercircuit conflict exists. $^{3}$ The Court's limitations in this respect have become increas-

1. Sce, e.g., Carrington, Crowded Dockets and the Courts of Appeals: The Threat to the Function of Review and the National Law, 82 HARv. L. REv. 542, 596-604 (1969); Leventhal, $A$ Modest Proposal for a Multi-Circuit Court of Appeals, 24 AM. U.L. REv. 881, 895900 (1975).

2. See Sup. Ct. R. 19.1(b); R. Robertson \& F. Kirkham, Jurisdiction of the Supreme Court of THE UNited States $\$ 322$ (2d ed. R. Wolfson \& P. Kurland 1951). Some critics of the discussion of intercircuit conflict have contended that there are actually very few real conflicts at any one time. Rochner \& Rochner, Certiorari-What Is A Conflict Between Circuits?, 20 U. CHr. L. REv. 656, 657-59 (1953) (criticizing definition of conflict in Stern, Denial of Certiorari Despite a Conflict, 66 Harv. L. Rev. 465 (1953)). Defining "conflict" is doubtless a difficult task, see Frankfurter \& Hart, The Business of the Supreme Court at October Term 1933, 48 HARv. L. REv. 238, 268 (1934), yet a recent study of conflict by Professor Floyd Feeney indicates that there are at least 75 direct conflicts each Supreme Court term on which certiorari is denied by the Court. U.S. CoMm'N on Revision of the Fed. Court Appellate Sys., Structure and Internal Procedures: Recommendations For Change, at 93.111 (1975) [hereinafter cited as Hruska Commission Report]. Professor Feeney analyzed 1859 cases on which the Supreme Court denied review in 19711972; law student coders found that of 727 cases containing claims of at least one conflict, there were 98 direct conflicts, 70 "strong partial" conflicts, 90 "weak partial" conflicts, and 708 cases without conflict. Id. at 101 (Table 9).

Regardless of the actual extent of conflict, the Hruska Commission Report notes that, even where conflict never develops, the mere possibility of conflict affects the legal process. This possibility breeds uncertainty, which leaves "individuals ... in doubt as to what rule will be applied to their transactions." Hruska Commission Report, supra at 14. Commentators on intercircuit conflict have also emphasized the significance of uncertainty in legal planning. Carrington, supra note 1 , at 551 (role of courts of appeals in creating predictable doctrines and principles of law); Griswold, Rationing Justice-The Supreme Court's Caseload and What the Court Does Not Do, 60 CoRnell L. REv. 335, 342 (1975) ("sharply rationed review" by Supreme Court means "it is hard to say that there is any national law on many subjects"); Hufstedler, Courtship and Other Legal Arts, 60 A.B.A.J. $545,546.47(1974)$ ("lack of certitude" in national law due to inadequate "ironing out" of "reported wrinkles" in national law). The absence of authoritative decision, and not the actual presence of conflict, is the "broader problem." HRUSKA Commission RePort, supra at 76.

3. Of petitions for certiorari filed in 1976 , just over six percent (.0619) were granted, [1976] Ad. OF. OF THE U.S. CourTS ANN. Rep., Table B-2, at 278 [hereinafter cited as A.O. ANN. REP.]; of all cases decided by the courts of appeals in that year, the Supreme Court heard less than one percent (.0098), id. Table 1, at 153. 
ingly apparent as Congress has subjected additional spheres of private behavior to federal agency regulation and as appeals from agencies to courts of appeals have proliferated. $\$$

Recent proposals intended, at least in part, to resolve intercircuit conflict have centered on the creation of new courts, such as a National Court of Appeals ${ }^{\overline{5}}$ or specialized courts of appeals. ${ }^{6}$ But these proposals have been sharply criticized, and the critics so far have prevailed. ${ }^{7}$ This

4. Most administrative appeals proceed from the agency's highest level to the courts of appeals. Carrington, supra note 1, at 597. See generally CoMmirtee on JUdicial Review, Ad. Conf. of U.S., Special. Statutory Provisions Governing Judicial Review of Federal Administrative Proceedings (pts. 1 \& 2) (1962) (listing statutory provisions).

5. This court would sit in Washington and occupy a position between the courts of appeals and the Supreme Court. Federal Judicial. Center, Report of The Study Group oN THE Caseload of THE Supreme Court (1972) (recommending, inter alia, that Supreme Court's screening function be delegated to such national court) [hereinafter cited as Freund REPoRT]; see Freund, A National Court of Appeals, 25 Hastings L.J. 1301 (1974). The Hruska Commission also recommended a national court of appeals. Unlike the Freund proposal, however, which would involve screening of cases by the National Court of Appeals, the Hruska Commission proposal would establish a decisional court with the power to decide cases referred to it by the Supreme Court and cases transferred to it by courts of appeals. HRUSKA CoMmission REPORT, supra note 2, at 30-39. See generally American Enterprise Institute, Proposais for a National Court of Apieals (1977) [hereinafter cited as Proposals].

6. See, e.g., H. Friendly, Federal Jurisdiction: A General View 154-68 (1973); Griswold, The Need for $A$ Court of Tax Appeals, 57 HARv. L. REv. 1153 (1944); Miller, $A$ Court of Tax Appeals Revisited, 85 YALE L.J. 228 (1975); Nathanson, Proposals for an Administrative Appellate Court, 25 AD. L. Rev. 85 (1972); Rifkind, A Special Court for Patent Litigation? The Danger of a Specialized Judiciary, 37 A.B....J. 425 (1951). There have also been numerous suggestions for aiding the courts of appeals through managerial and operational improvements. See, e.g., II Advisory Couvcil. for APPellite Justice, Appellite Justice: 1975, at 1-139 (materials for conference sponsored by Federal Judicial Center and National Center for State Courts) (discussing limitation of oral argument; decisions without reasons and oral opinions; unpublished opinions; experimental uses of staff; prehearing screening) [hereinafter cited as Appellate Justice]; AB.t Comm's on Standards of Judiclal Administration, Standards Relating to Appellate Courts (1977) (recommending guidelines for procedure in American appellate courts). Efficiency proposals, however, fail to restructure the conflict-producing system.

7. P. Bator, P. Mishkin, D. Shapiro, \& H. Wechsler, Hart \& Wechisle's The Federil Courts and the Fideral System 2-3 (2d ed. 1977 Supp.) (citing sources) [hereinafter cited as HART \& WechsLer]. See also Proposals, supra note 5, at 27-36 \& nn.72-92.

The Freund Report's proposal was criticized primarily for its relegation of the screening function to the National Court of Appeals. Opponents felt that such a device would rob the Supreme Court of docket control, which is viewed as a policy tool because it indicates what issues the Court considers significant. See, e.g., Black, The National Court of Appeals: An Unwise Proposal, 83 Yale L.J. 883, 888-91 (1974); Blumstein, The Supreme Court's Jurisdiction-Reform Proposals, Discretionary Review, and IVrit Dismissals, 26 VAND. L. REV. 895, 911-16 (1973); Symposium-Should the Appellate Jurisdiction of the United States Supreme Court Be Changed? An Evaluation of the Freund Report Proposals, 27 RUTGers L. ReV. 878, 918-19 (1974); Warren, A Response To Recent Proposals To Dilute the Jurisdiction of the Supreme Court, 20 Loy. L. REv. 221, 226-27 (1974).

The Hruska Commission's proposed National Court of Appeals has also been criticized, if to a lesser degree. HarT \& WechsLck, supra at 4. The focus of attack has been the transfer power, by which courts of appeals could transfer cases of their choice to the National Court of Appeals for decision. Hrusk Commission Report, supra note 2, at 34-38. Critics fear diminution of the power and prestige of the Supreme Court if the new 
Note approaches the problem from a different perspective. It argues that adoption of the law of the circuit rule was not historically inevitable and that models for a single national appeals court inferior to the Supreme Court existed when the circuit courts of appeals were first established and continue in existence today. Moreover, the Note contends that such a national appeals court would satisfy the institutional needs of courts and litigants. The Note thus proposes that Congress legislate the changes necessary to formalize the courts of appeals as regional panels of one national appellate court inferior to the Supreme Court. The legislation should provide that, at least in areas of agencyadministered law, an en banc decision of the court of appeals of one circuit be binding on every lower federal court.

\section{The Need for Uniformity in National Law}

The growth in this century of "the new federal common law" judicial interpretations of federal statutory law-has produced a strain on the federal judiciary. ${ }^{9}$ At the federal appellate level increased dock-

court may decide such transferred cases without any supervision. See, e.g., Alsup, Reservations on the Proposal of the Hruska Commission to Establish a National Court of Appeals, 7 U. ToL. L. Rcv. 431, 446-51 (1976). But see Hruska, The National Court of Appeals: An Analysis of I'iewpoints, 9 Creightox L. REv. 286, 288 (1975). See also Haworth, Circuit Spliting and the "New" National Court of Appeals: Can the Mouse Roar?, 30 Sw. L.J. 839, 859-64 (1976) (supporting National Court).

8. Friendly, In Praise of Erie-And of the New Federal Common Law, 39 N.Y.U.L. REv. 383 (1964). Judge Friendly describes the difference between the new and old federal common law as follows:

My view is that, by banishing the spurious uniformity of Swift $v$. Tyson-what Mr. Justice Frankfurter was to call "the attractive vision of a uniform body of federal law" but a vision only-and by leaving to the states what ought to be left to them, Erie led to the emergence of a federal decisional law in areas of national concern that is truly uniform because, under the supremacy clause, it is binding in every forum, and therefore is predictable and useful as its predecessor, more general in subject matter but limited to the federal courts, was not. The clarion yet careful pronouncement of Erie, "There is no federal general common law," opened the way to what, for want of a better term, we may call specialized federal common law. I doubt that we sufficiently realize how far this development has gone-let alone where it is likely to go.

Id. at $\mathbf{4 0 5}$ (footnotes omitted).

9. The recent growth in the federal appellate docket is enormous: in 1962, 4,823 cases were filed in the courts of appeals; in 1969, 10,248; and in 1976,18,408. This represents a 281.7\% increase over 15 years. A.O. ANN. REP., supra note 3, Table 1, at 153. Judicial personnel has increased on and off the bench. Pending legislation would provide 110 additional district judges and 35 additional circuit judges (21 going to two circuits alone, the fifth and ninth). H.R. 7843, 95th Cong., 2d Sess. (1978), passed by House, at 124 ConG. REc. H717-32 (daily ed. Feb. 7, 1978). (The Senate version's omission of a merit selection section has prompted appointment of conferees on the bill, 124 CoNG. REc. H905-08 (daily ed. Feb. 9, 1978).) These positions would increase the number of district and circuit judges to over 600 , not counting senior judges. A.O. ANN. REP., supra note 3, Table 1 , at 76. The total staff in clerks' offices in 1976 was 2,557. Id., Table 13, at 94 .

The federal appellate judiciary itself has begun to articulate its concern over the increased strain on the judicial system. See, e.g., Hearings Before the Comm'n on Revision 
ets ${ }^{10}$ are largely attributable to the creation by Congress of multifarious federal administrative agencies. ${ }^{11}$ With a view to creating greater uniformity in regulatory law, Congress has delegated to these bodies the responsibility for framing rules and orders that have the status of law. ${ }^{12}$ The rules and orders are often the subject of litigation within the agencies and of subsequent appeals to the courts of appeals. ${ }^{13}$

Despite the congressional intention to create uniform national law, a

of the Federal Court Appellate System, First Phase, at 34, 81-90, 352, 355, 514, 638, 1067, 1092 (Aug.-Oct. 1973) (hearings conducted pursuant to Act of Oct. 13, 1972, Pub. L. No. 92-489, 86 Stat. 807) (statements of various circuit judges) [hereinafter cited as Hruska Hearings].

10. See H. Friexdly, supra note 6, at 15-54. For an earlier compilation of perspectives on the problem of burgeoning court dockets, sce THE CourTs, ThE Public, and the LAw Explosion (H. Jones ed. 1965).

11. "Administrative agencies" is taken to encompass both independent commissions created by Congress, such as the National Labor Relations Board, and bodies within the executive branch, such as the Internal Revenue Service. Judge Friendly noted the similarity between the two:

The old idea that administrative appeals concern mainly the independent agenciesthe NLRB, FCC, FTC, CAB, FPC, SEC, FMC, and AEC-has gone by the board, although we are not yet fully aware of it. It is not going too far to predict that by the end of the decade appeals to courts of appeals from agencies within the exccutive branch will be as numerous as those now coming from all independent commissions other than the NLRB.

H. FrIENDLX, supra note 6, at 34-35. Judge Friendly lists a sample of recent legislation imposing yet more review responsibility on the courts of appeals. Id. at 34 n.108. Accord, Hruska Hearings, supra note 9, at 83.90 (statement of Judge J. Skelly Wright, United States Court of Appeals, District of Columbia Circuit).

There are at present 51 "non-cabinet executive agencies," such as the National Labor Relations Board; 11 "cabinet level departments," such as the Treasury Department; 345 "sub-agencies," such as the Internal Revenue Service and the Bureau of Labor Statistics; and 36 "committees, commissions, and boards," such as the United States Metric Board. See Letter to author from Peter J. Petkas, Director, Project Management Staff (undated), (on file with Yale Law Journal); President's Reorganization Project, Executive Office of the President of the United States, Current Inventory of Organizational Units Within the Executive Branch, at 3 (April 1977) (including photocopied updated chart) (on file with Yale Law Journal).

12. See, e.g., G. Robinson \& E. Gellhorn, The Administrative Process 102-06 (1974); HRUSKA COMMISSION REPORT, supra note 2, at 7-8. The congressional intent is frequently incorporated into the statute enacted. E.g., National Labor Relations Act $\$ 1,29$ U.S.C. $\$ 151$ (1970); see NLRB v. Nash-Finch Co., 404 U.S. 138, 142-43 (1971).

Recently, environmental legislation has concentrated on federalization of pollution standards to create a national minimum level. Thus, in 1970 an amendment to $\$$ 105(a)(1)(A) of the Clean Air Act, 42 U.S.C. $\$ 1857 \mathrm{c}(\mathrm{a})(1)(\mathrm{A})$ (1970), was reported out by the House of Representatives as a measure "to establish nationwide standards ... [so that] the war against air pollution will be carried on throughout the Nation rather than only in particular geographical areas." H.R. REP. No. 91-1146, 91st Cong., 2d Sess. 2 (1970), re printed in [1970] U.S. Code CoNg. \& AD. News 5356, 5357. The courts of appcals have noted the congressional intent to provide for uniform regulations by administrative agencies. E.g., Pan Am. World Airways, Inc. v. CAB, 517 F.2d 734, 745 (2d Cir. 1975), discussed in Vestal, Relitigation by Federal Agencies: Conflict, Concurrence and Synthesis of Judicial Policies, 55 N.C.L. Rev. 123, 145-46 (1977).

13. Of appeals filed in the courts of appeals in 1976 , about $13.7 \%(.1366)$ involved appeals from actions of administrative agencies. See A.O. ANN. REP., supra note 3, Tables I \& 12 , at 153,165 . 
decision by a court of appeals in an administrative appeal binds only the circuit in which that court sits. Since decisions of many agencies may be appealed to any circuit, ${ }^{14}$ the law-of-the-circuit rule often produces nonuniform decisions from circuit to circuit. Litigants, including federal agencies, ${ }^{15}$ at times take advantage of the nonuniformity by shopping for a favorable circuit. ${ }^{10}$

For many years it was generally accepted that intercircuit conflict would be resolved by the Supreme Court. ${ }^{17}$ This assumption was based on the Court's role as the ultimate arbiter of federal law ${ }^{18}$ and was supported by the Court's willingness, in choosing the cases in which to grant certiorari, to take into consideration the existence of conflicting decisions by courts of appeals. ${ }^{10}$ The experience of the last twenty-five years, however, has made apparent that the Supreme Court cannot by itself maintain uniformity in federal law. ${ }^{20}$ The Court does not review a sufficient number of cases each term to resolve all intercircuit conflict or indeed even a small fraction of it. ${ }^{21}$ Consequently, the Supreme Court is neither the court of last resort for most litigants nor the final arbiter of all federal law. Indeed, nonconstitutional areas such as agency-administered law are generally left by the Supreme Court to the courts of appeals. ${ }^{22}$

14. E.g., 15 U.S.C. $\$ 45$ (c) (1970) (Fed. Trade Comm'n); I.R.C. \$ 7482(a) (Internal Revenue Serv.); 29 U.S.C. $\$ 160$ (e) (Nat'l Labor Rel. Bd.); see Carrington, supra note 1, at 597. But see, e.g., 47 U.S.C. $\$ 402(b)$ (1970) (review of Fed. Communications Comm'n actions in District of Columbia Circuit only).

15. Both Judge Leventhal and Professor Vestal note the "policy" of relitigation by the government. Leventhal, supra note 1, at 904-05; Vestal, supra note 12, at 123-27. Judge Leventhal, however, does not dismiss the impact of nongovernmental "[m]ultiple litigation," especially on the part of private taxpayers. Leventhal, supra note 1 , at 905 .

16. Sec, e.g, Carrington, supra note 1, at $598-601$ \& $n .234$ (describing race to circuits involved in General Elec. Co., 150 N.L.R.B. 192 (1964), modified per curiam, 358 F.2d 292 (2d Cir.), vacaled, 382 U.S. 366 (1966)); Leventhal, supra note 1, at 909 (describing similar race in EPA case).

17. See Stern, supra note 2 , at 465 (quoting treatises).

18. See id.; Warren, supra note 7 , at 226.

19. Leventhal, supra note 1, at 887-88; Stern, supra note 2, at 465 ; see Sup. Cr. R. 19:

1. A review on writ of certiorari is not a matter of right, but of sound judicial discretion, and will be granted only where there are special and important reasons therefor. The following, while ncither controlling nor fully measuring the court's discretion, indicate the character of reasons which will be considered:

(b) Where a court of appeals has rendered a decision in conflict with the decision of another court of appeals on the same matter ....

20. The trend was first discerned in Stern, supra note 2, at 465-70. See Hruska ComMISSION REPORT, supra note 2, at 18-19; Leventhal, supra note 1, at 888.

21. The Court is now operating close to its capacity, see Burger, Chief Justice Burger Isstes Yearend Report, 62 A.B.A.J. 189, 190 (1976) (noting "vastly expanded" caseload); Carrington, supra note 1 , at 553; p. 1219 \& note 3 supra.

22. See Leventhal, supra note 1 , at 910 (quoting Mobil Oil Corp. v. FPC, 417 U.S. 283, $309 \cdot 10(1974))$. 
Yet the nature of a law should not be dispositive of the extent to which it is uniformly applied..$^{23}$ Congress did not intend that the national authority of agency-administered law be diminished merely because much of that law is technical and nonconstitutional. Regulatory law in fact may require uniformity to an extent greater than other areas of law. Many individuals affected by tax and labor law, for example, must engage in complicated day-to-day management and planning based on fixed legal rules. ${ }^{2-4}$ The federal government has created the very complexity with which these planners must deal, and yet the complexity is not uniform throughout the federal system..$^{25}$ An institution is needed to maintain uniformity in federal common law. This Note argues that the courts of appeals, notwithstanding that there are at present eleven such courts sitting in different areas of the country, are best suited to the task.

\section{The Circuit Courts of Appeals Act of 1891}

The courts of appeals were created, after decades of debate, ${ }^{20}$ by the Circuit Courts of Appeals Act of 1891 (Evarts Act). ${ }^{27}$ The division of the courts of appeals into geographic circuits was by no means an obvious decision. The debate preceding enactment reveals that the

23. Dean Griswold has noted that nonuniformity means that justice is rationed: The loss is not merely in the arbitrary or haphazard nature of the justice which results, including almost complete denial of appellate review in various aspects of the law, but it is also a very important institutional loss through the lack of a substantial number of authoritative appellate decisions for the guidance and control of the lower courts, thus leaving the courts of appeals, in particular, rather at large in many fields. Griswold, supra note 2, at 347.

24. See, e.g., Hruska Hearings, supra note 9, at 21 (Dean Griswold) (in labor and tax especially "people ought to know nationwide what you can do and what you can't do"); Miller, supra note 6, at 228. Tax and labor law have long been noted for uncertainty due to intercircuit tension. HRUSKa Commission REPORT, supra note 2, at 145-51 (tax); id. at 154-57 (report of survey by Prof. Clyde Summers of attitudes of labor law practitioners); Carrington, supra note 1 , at 611 (labor); Miller, supra note 6, at 228.29 \& nn.1, 3-5 (tax); Shapiro, Book Review, 86 Yale L.J. 1532, 1544-45 (197i) (calling for uniform rules in labor law).

25. See HRuska Commission Rerokt, supra note 2, at 144-68 (survey of private and agency attorneys conducted by Commission revealed general perception of intercircuit conflict as problem in legal planning); Carrington, supra note 1, at 596.97 (discussing "frustrating consequences for legal planning" and "unresolvable confusion" engendered by "balkanized system of separate circuits"); Rosenberg, Unresolved Questions of National $L a w$, in V APpelLATE JUSTICE, supra note 6 , at $17-25$ (response of tax bar to Professor Rosenberg's questionnaire revealed concern for uniformity in many areas).

26. F. Frankfurter \& J. Landis, The Business of the Supreme Court 70-85, 96-102 (1928). Apparently, the first proposal came in 1848. Id. at 70. Thereafter, the bills drafted to establish an intermediate appellate court reappeared every three or four years until ultimate success in 1891 . Id. at $70-72,78-85$.

27. Ch. 517, 26 Stat. 901. 
scheme of intermediate appellate courts ultimately adopted-with its concomitant, the law-of-the-circuit rule-was but one of several proposals considered. ${ }^{28}$

Nearly every suggestion entertained by Congress was drawn from the experience of states whose judicial systems had been altered to accommodate growing populations and the consequent increased demand placed on the judicial process. The highest courts of those states were overworked, their dockets were backlogged, and litigation was, as a result, significantly delayed.29 As similar congestion developed in the Supreme Court after the Civil War, ${ }^{30}$ Congressmen and commentators naturally made reference to the reforms adopted at the state level.

In response to congested dockets of the highest state appellate courts, a number of states had created inferior appellate courts. ${ }^{31}$ These courts were appellate divisions-or "law terms"-of the trial courts. Each division was responsible for correcting the errors of law made by the particular trial courts over which it sat. ${ }^{32}$ The jurisdiction and authority of each appellate division were thus confined to a portion of the state's trial courts and could not extend to trial courts supervised by the other appellate divisions. ${ }^{33}$ Although such reforms relieved the dockets of

28. F. FRANKFURTER \& J. LANDIS, supra note 26 , at $80-81$.

29. In 1884 the American Bar Association commissioned a study to determine what delay and uncertainty existed in state courts. The study was proposed by David Dudley Field, who lamented the problems caused by crowded dockets in his state, New York. REport of the SeVenth ANNual MeEting of the AMerican Bar Association 74-77 (1884) [hereinafter cited as SEvENTH ABA REPORT]. The results of the study indicated that high courts in other states were also significantly delayed. Report of the Special Committee Appointed to Consider and Report Whether the Present Delay and Uncertainty in Judicial Administration Can Be Lessened, and If So, By What Means, in REPORT OF THE EIGHTH Annual Meetivg of the American Bar Association 323, 368-449 (1885) [hereinafter cited as EIGHTH ABA REPORT].

30. See F. Frankfurter \& J. Landis, supra note 26, at 69 ("The Supreme Court docket became a record of arrears [in the post-Civil War period].") Both bench and bar called for ameliorative action. See 21 Coxg. Rec. 3403 (1890) (Rep. Culberson, quoting from speech of Mr. Justice Harlan) ("The remedy is not with the Supreme Court. After a service of ten years as a member of that court, I am able to say that it moves with all the rapidity that is physically possible. Its members can do no more than they are doing.' "); Majorily Report on the Relief of the United States Courts, in REPORT OF THE FIFTH ANNual Méting of the AMerican Bar .Issociatiox 343, 344-45 (1882) [hereinafter cited as Majority Report] [volume hereinafter cited as FIFTH AB.t REPORT]. Many lawyers and commentators noted the uncertainty that is the byproduct of delay. See, e.g., REPORT OF the Thirteenth AnNual Meeting, of tife AMericin BAr Association 31-40 (1890) [hereinafter cited as THIRTENTI ABA RePoRT]; Raymond, Relief of the Federal Court's Docket, in Proceedings of the Illinois Siate Bar Association at its Twelfth ANnual Meeting 65, 66-67 (1889); 13 Conc. Rec. 3790 (1882) (Sen. George).

31. R. Pound, Orcanization of Courts 225-4I (1940).

32. Id. at 226. Dean Pound traced appellate divisions to the model of the King's Bench in England. Id.; see I W. Holdsworth, A History of ENGLish Law 204-11 (3d ed. 1922).

33. See, e.g., 3 Proceedings and Debates of the Constitutional Convention of the State of New York, Held in 1867 and 1868, in the City of Albany 2175 (Mr. Fuller, 
the highest state courts-at least for a while $e^{34}-$ they also produced conflicts among the appellate divisions. ${ }^{35}$ The Evarts Act imitated these state court systems by creating federal appellate divisions that supervised particular trial courts.

The idea that the federal courts of appeals should assume greater responsibility for national uniformity can be gleaned from the experience of other state court reforms. Instead of creating appellate divisions, some states first attempted to ease high-court congestion by splitting that court into panels. ${ }^{36}$ Each panel of the court could render an opinion binding on the entire state. In these states intermediate appellate courts eventually were created and were treated as successors to the high court panels; principles of stare decisis were thus applicable to them. The idea of panel authority gained practical expression on the federal level in the late nineteenth-century proposal to divide the United States Supreme Court into panels of coequal authority. ${ }^{37}$

\section{A. The State Courts}

The debate on federal court reform in the nineteenth century indicates that the drafters of the Evarts Act had three experiences at the state level on which to draw. First, New York and Illinois built their intermediate appellate courts on the trial court foundation. These appellate divisions were regional, corrective supervisors of the lower courts. Second, Missouri and Ohio tried similar appellate divisions, found that they produced conflict, and-subsequent to adoption of the Evarts Act-changed to supreme courts sitting in panels. Finally, California began with a supreme court in panels, which, in the years after the Act's adoption, evolved into intermediate appellate courts that sat as regionally placed panels of a statewide court.

noting confinement of authority to eight geographical areas, each governed by eight general terms) [hereinafter cited as N.Y. Constirutronal Convention Procerdings]; pp. 122729 infra. Moreover, the judges who sat at appellate (general) term were trial court judges from the same circuit. A. Chester \& E. Williams, Courts and Lawrers of New YORK, A HISTORY 1609-1925, at 858 (1925).

34. See Seventh ABA Report, supra note 29, at 77 (David Dudley Field: "A little while ago the calendar was cleared, and we all thought that we had reached the judicial millenium in New York. But it is crowded again.")

35. See pp. 1227-28, 1229-30 infra.

36. Although the drafters of the Evarts Act referred to one or two such states, see p. 1231 infra, the popularity of divisional sittings in the court of last resort became more pronounced by 1930 , when 20 of 28 states with large supreme courts had dealt with congestion in that manner. Note, En Banc Hearings in the Federal Courts of Appeals: Accommodating Institutional Responsibilities (pt. 1), 40 N.Y.U.L. REv. 563, 565-67 (1965).

37. See pp. 1232-36 infra. 


\section{New York and Illinois: Appellate Divisions}

The drafters of the Evarts Act relied on the state court systems of New York and Illinois, ${ }^{38}$ which contained intermediate appellate courts with equal but geographically circumscribed authority. The New York system in 1846 consisted of trial courts (the supreme court) sitting in eight districts and one appellate court (the court of appeals). ${ }^{39}$ The Constitution of 1846 interposed between the trial courts and the court of appeals eight regionally restricted "general terms" of the supreme court, which took appeals from those trial courts in their districts. ${ }^{40}$ By 1867 , however, the eight terms had produced many conflicting opinions $^{11}$ that the court of appeals could not resolve. ${ }^{42}$ A constitutional convention called that year attempted to reduce the conflict by simply decreasing the number of general terms from eight to four. ${ }^{43}$ Some convention delegates warned that this tactic would only reduce the quantity of conflicts, not the divisive impact on state law. ${ }^{44}$ They proposed to divide the court of appeals into panels of coordinate authority, ${ }^{45}$ designed to increase the court's capacity while maintaining

38. See pp. 1232-34 infra.

39. N.Y. Const, of 1846, art. VI; A. Chester \& E. Williams, supra note 33, at 684.

40. A. Chester \& E. Williams, supra note 33, at 685 ; H. ScotT, The Courts of the State of New York, Their History, Development and Jurisdiction 251-52 (1909). The judges of the supreme court were assigned to general term usually only upon reelection to the trial court. The general terms were held once a year in each district. A. ChESTER \& E. WilliaMs, supra note 33 , at 859-60.

41. A. Chester \& E. Williams, supra note 33 , at 696, 706; see 3 N.Y. Constitutional Convention Proceedings, supra note 33, at 2175-76, 2215-16, 2219, 2287, 2362 (statements of various delegates); $4 \mathrm{id}$. at 2411, 2514-18 (same). For a poignant description of the problems caused by conflict, see $i d$. at 2516-18.

42. See 3 N.Y. Constitutional. Convention Proceedings, supra note 33, at 2215-16.

43. N.Y. Const. of 1846, art. VI (1869). The 1867 Convention proposed a complete constitution, 5 N.Y. Constitutional Convention Proceedings, supra note 33, at 3958-71, but the Act submitting the constitution to a referendum required separate votes on the constitution as a whole and on three specific articles of it, Act of April 24, 1869, ch. 318, $\$ 2,1869$ N.Y. Laws 687 . Only the judiciary article was ratified. A. Chester \& E. Williams, supra note 33 , at 709 .

44. Even a member of the Convention's Committec on the Judiciary who had endorsed the reduced terms admitted their inadequacies: "I am not quite stre but what the evil of conflict of decisions between four general terms thus constituted would be as great as between the eight general terms that we now have . . ." 4 N.Y. Constitutional CoNvENTION PROCEEDINGS, supra note 33, at 2414 (Mr. Hale).

45. Mr. Cooke, delegate from Ulster, introduced the first plan. 3 id. at 2285. Mr. Cooke said in defense of his plan:

I presented this plan with the belief, that of all the evils to be apprehended from any system, the greatest was incapacity to do its business promptly. I think it is far better to have decisions of doubtful propriety and justice than not to have decisions at all. ... I had rather to-day see half-a-dozen co-ordinate courts of last resort established in this State ....

Id. at 2387. A second proposal to divide the Court of Appeals was introduced later in the convention. Id. at 2383 . 
uniformity. But these proposals failed. ${ }^{46}$ By 1884 , conflict still persisted; litigants, dissatisfied with the regionally restricted general term decisions, flooded the court of appeals for final, uniform rulings of law. ${ }^{47}$

The architects of the Illinois system of intermediate appellate courts $^{48}$ were influenced by the systems in New York and Ohio. ${ }^{40}$ Illinois, like New York, provided for appellate divisions whose judicial personnel were trial court judges. ${ }^{50}$ Also like New York, Illinois sought to relieve the case burden on the state's highest court, the Supreme Court. ${ }^{51}$ The debates of the constitutional convention of 1870 reveal, moreover, that Illinois considered and rejected a proposal for dividing its supreme court into panels. ${ }^{52}$ The final provision for an intermediate court enabled the legislature to create appellate divisions of the circuit (trial) courts after $1874,{ }^{, 33}$ and the General Assembly created four such divisions in $1877 . .^{54}$

But the Illinois system differed from that of New York in two important respects. First, the Illinois Supreme Court sat once each term in three geographical subdivisions of the state. ${ }^{55}$ The four intermediate

46. Id. at 2303,2384 (defeat of two proposals); see N.Y. Consr. of 1846, art. VI (1869). To help eliminate the backlog in the court of appeals, the Convention created a temporary commission to decide pending cases on the high court's docket. N.Y. Consr. of 1846, art. VI, $\$ \$ 4,5$ (1869); see R. Pound, supra note 31, at 201-02. The temporary use of supreme court commissions was common in nineteenth-century state court systems. Id. Pound characterized these commissions as temporary divisions of the supreme courts. $I d$. at 209. In doing so he reflected statements made in the New York debates. See 3 N.Y. Constitutional Convention Procendings, supra note 33, at 2292-93 (Mr. Cooke). But the commissions have an even closer parallel to the currently proposed National Court of Appeals. Compare N.Y. Const. of 1846, art. VI, $\$ \S 4,5$ (1869) with HRUSKA Commission REPORT, supra note 2 , at $32-34$.

47. SEVENTH ABA REPORT, supra note 29, at $76-7$; That Shall Be Done to Relieve Our

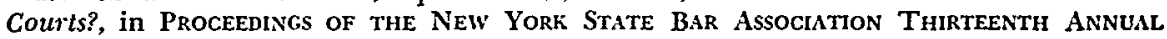
MeEting 239 (1890). A second Court of Appeals commission sat from March 5, 1891 to Oct. 1, 1892. A. Chester \& E. Williams, supra note 33, at 812-14.

48. Ill. Const. of 1870 , art. VI, $\$ 11$, reprinted in 2 Debatcs and Proceedings of the Constitutional. Convention of the State of Illinois, at 1874-75 (1870) (ratified July 2, 1870, see N. Garvey, The Government and Administration of Illinois 28 (1958)) [debates hereinafter cited as Illinors Debates]; Act of June 2, 1877, 1877 Ill. Laws 69.

49. See 1 Illinois Debates, supra note 48, at 999, 1034. For discussion of the development of the Ohio system, see pp. 1229-30 \& notes 61-69 infra.

50. Act of June 2, 1877, $\$ 1$, 1877 Ill. Laws 69; see 1 Illinors Debates, supra note 48, at 999 .

51. 1 Illinors Debates, supra note 48 , at 999 .

52. Id. at 995-97. There was discussion of allowing the supreme court to establish divisions by rule of court, id. at 996 , but the judiciary article ultimately adopted required a quorum of four out of seven justices. ILL. Const. of 1870 , art. VI, $\$ 2$, reprinted in 2 IlLINOIS Debates, supia note 48 , at 1874 .

53. Ill. Const. of 1870 , art. VI, $\$ 11$, reprinted in 2 Illinors Debates, supra note 48, at $1874-75$.

54. Act of June 2, 1877, 1877 Ill. Laws 69.

55. These geographical subdivisions were known as "grand divisions." ILL. Const. of 1870 , art. VI, $\S \S 4,5$, reprinted in 2 Illinols Debates, supra note 48 , at 1874 . The 
appellate courts sat at different times of the year ${ }^{56}$ to enable the supreme court to attend to appeals in one geographical area without delaying other courts. The supreme court supervised each intermediate appellate court individually and thus was able to assure uniformity. ${ }^{57}$ Second, appeal from the appellate courts to the supreme court was generally as of right under the implementing statute of $1877 . .^{58}$ And it was the practice in instances of conflicting intermediate court decisions "to remove a test cause to the Supreme Court for examination and final determination." $\overline{\mathrm{w}} 0$ Thus Illinois provided for at least two safeguards against conflict in its appellate division system: a supreme court that practiced geographic supervision and a procedure for appeal and certification that guaranteed resolution of conflict. It is not surprising that contemporary commentators from Illinois believed that an appellate division plan such as theirs would not produce conflict. ${ }^{60}$

\section{Ohio and Missouri: Appellate Divisions Yield to Panel Authority}

Some states experimented with an appellate division structure but ultimately abandoned it due to the conflict of decision the system produced. Ohio, like New York, attempted to relieve the workload of its highest court by interposing appellate courts (district courts). ${ }^{61} \mathrm{But}$ the Ohio system initially differed in one respect: it provided that one

Illinois Reports after 1877 show that appeals to the supreme court were filed in three locations: Ottowa, Mt. Vernon, and Springfield.

56. Act of June 2, 1877, $\$ 2,1877$ III. Laws 69 .

57. The commentary of the Illinois bar from 1877 until 1890 is unanimous that the state did not suffer conflict among its appellate courts. See, e.g., FIFTH ABA REPORT, supra note 30, at 50-51, 91-93 (Illinois delegates); 13 CoNG. REc. 3465-66 (1882) (Sen. Davis of Illinois).

58. Act of June 2, 1877, $\$ 8,1877$ Ill. Laws 69 (appeal as of right where damages more than $\$ 1000$; permissive appeal on certification from intermediate appellate court available where less than $\$ 1000$ ). Appeals could be taken to the supreme court as it sat in a grand division other than the one in which the case arose. ILL. CoNsT. of 1870 , art. VI $\$ 8$, reprinted in 2 Illinois Debates, supra note 48 , at 1874; Act of June 2, 1877, $\$ 16,1877$ Ill. Laws 69; see Gross v. People, 95 Ill. 366 (1880).

59. FIFTH ABA REPORT, supra note 30, at 55 (C.C. Bonney, ABA delegate from Illinois).

60. See note 57 supra.

61. OHo Const. of 1851 , art. IV, $\$ \$ 5,6$. The development of appellate divisions in Ohio, however, was preceded by a history different from that of New York. In the early nineteenth century, the Ohio Supreme Court consisted of four judges who sat in two panels on circuit in review of trial court decisions. 1 A History OF THE CourTs AND LAWYers of OHIo 219-20 (C. Marshall ed. 1934) [hereinafter cited as History of OHIo]. Gradually, it became the practice for the court to hold an annual en banc session in Columbus, and there came to be a clear distinction between the "Supreme Court" sitting on circuit and the "Supreme Court in Bank," sitting as a whole to decide reserved questions. Id. at 220-21. In 1885 it was determined that the district courts succeeded the supreme court in its circuit-riding role, and the new supreme court was the successor of the "Supreme Court in Bank." Webster v. State, 43 Ohio St. 696, 4 N.E. 92 (1885), cited in I History OF OHIo, supra at 221. 
supreme court judge sit on each district court. ${ }^{62}$ As it turned out, the supreme court judges had enough work to do in their own court and quickly ceased to fulfill their lower court duties. ${ }^{63}$ Consequently the district courts were left in the care of trial court judges, who slighted their appellate work for the sake of their trial duties. ${ }^{6 t}$

The Ohio intermediate appellate courts were thus appellate divisions of trial courts; both the geographic boundaries and the personnel of the two coincided. The result was conflict ${ }^{65}$ and an even more congested supreme court docket. ${ }^{66}$ Ohio's constitutional convention of 1873 considered the problem, ${ }^{67}$ and in 1883 the legislature decided to allow the supreme court to sit in divisions. ${ }^{68}$ This provision was implemented in $1892 .{ }^{69}$

Missouri adopted an appellate division plan patterned after the New York example ${ }^{70}$ and found it to be a failure. ${ }^{71}$ It was quickly abandoned, ${ }^{72}$ and later, in 1890 , the state turned to a supreme court sitting

62. Ohio Const. of 1851 , art. IV, $\S 5$; 1 History of OhIo, supra note 61 , at 195 . The other judges to serve on the district courts were common pleas judges OHIO Const. of 1851 , art. IV, $\$ 5$.

63. 1 History of OHo, supra note 61 , at 201. The Ohio experience with circuit-riding by high court judges is parallel to the failure of circuit-riding on the federal level. HART \& WECHSLER, supra note 7 , at 37 ("privilege of non-attendance" more common as country grows). See generally Vestal, supra note 12, at 130 (federal circuit courts "extensions" of Supreme Court, since Justices sat on circuit courts). The Illinois debates of 1870 noted this failure and specifically rejected the Ohio model of supreme court justices riding circuit. 1 Illinois Debates, supra note 48, at 1038-39.

64. I Official Report of the Proceedings and Debates of the Third Constitutional Convention of OHIo 623-24 (1873) [hereinafter cited as OHIo RePORT]; Skeel, Constitutional History of Ohio Appellate Courts, 6 Cheve-MAR. L. Rev. 323, 328 (1957).

65. I OHIO REPORT, supra note 64 , at 734.

66. Id. at 622 .

67. Id. The proposed constitution of 1874 , derived from those debates, was not ratified. I HISTORY OF OHIO, supra note 61, at 202.

68. 1 History of OHIo, supra note 61 , at 206. The district courts were abolished and replaced by independently staffed intermediate appellate courts, the circuit courts. Id. at 202-04.

69. 1892 Ohio Laws 317. Apparently the legislature was reluctant to return to a permanently divided court, since it provided for two temporary commissions between 1875 and 1885. 1 History OF OHIo, supra note 6I, at 222-23. But the commissions had all the authority of a statewide court, see Railroad Co. v. Hutchins, 37 Ohio St. 282, 293 (1881), and probably eased the reintroduction of a divided high court.

Ohio ultimately abandoned division of the supreme court in 1913. The court was required to sit en banc and review every case in which the pancl decisions were not unanimous. The court was thus not significantly relieved of its appellate burden by sitting in divisions that just passed the case up to the full bench. See 1 History of OHo, supra note 61 , at 223.

70. Mo. Const. of 1865, art. VI, \$ 12. See 21 CoNG. Rec. 10305 (1890) (Sen. Vest) (“[W]c established what was called a district court in analogy with the practice in the State of New York as to their supreme court. . . . [T] here [were] a number of districts or divisions in the State, composed of five of the circuit judges, who sat in banc and heard within a limited jurisdiction cases that came to them ....")

71. See 21 Cong. Rec. 10305 (1890) (Sen. Vest) (appellate divisions "the most miserable failure ever attempted").

72. Mo. Const. of 1965 , art. VI, $\$ \S 1,12$ (1870); R. Pound, supra note 31, at 229. 
in divisions. ${ }^{73}$ The intermediate appellate courts that also developed in this period were independent of the trial courts but were required to transfer to the supreme court cases in which they felt compelled to disagree with another intermediate appellate court. ${ }^{74}$

\section{California: Panel Authority and Uniformity}

The chief opponent of the federal courts of appeals in the Senate debate in 1890, Senator Vest of Missouri, relied on the court systems of both California and Rhode Islandis to support the plan for a divided Supreme Court. ${ }^{76} \mathrm{He}$ drew more heavily on the California system. ${ }^{77}$ California's highest court was divided into two panels in 1879, each panel rendering decisions with the statewide authority of the full court. ${ }^{78}$ This was the model for the proposal to divide the United States Supreme Court into panels..$^{79}$

The importance of California to analysis of federal appellate courts does not end with the rejection of the panel alternative by the Evarts Act. The subsequent development of the California court structure provides a model for panel authority to which reference can be made in contemporary study of the federal courts of appeals. As the state's vast territory filled with a growing population, it became necessary to place appellate courts throughout the state for the convenience of litigants. ${ }^{80}$ California's District Courts of Appeal-intermediate ap-

73. Mo. Consr. of 1875, art. VI, amend. of 1890; R. Pound, supra note 31, at 216, 229-30. The Missouri Supreme Court may still sit in divisions under the current constitution, which was adopted in 1945 . Mo. Const. art. 5 , $\$ 7$.

74. Mo. Const. of 1875 , art. VI, amend. of $1884, \S 6$. This certification provision still exists. Mo. Const. art. $5, \S 10$. The division of the supreme court, however, occurred after the creation of the intermediate courts.

75. 21 Cong. Rec. 10304 (1890) (Sen. Vest). Senator Vest purported to speak for a fourmember minority of the Judiciary Committee in opposing the bill, see id. at 10308, but only three senators signed the Committee's minority report, see SENATE CoMm. ON THE Judiciary, Views of the Minority, S. Rep. No. 1571, 5lst Cong., 1st Sess. (Aug. 8, 1890) (signed by Senators Edmunds, Ingalls, and Vest).

76. See 21 Conc. Rec. 10303 (1890) (text of proposed bill).

77. See 21 CoNG. REc. 10303-04 (1890) (Sen. Vest, quoting extensively from California Constitution of 1879).

78. Niles v. Edwards, 95 Cal. 41, 42-43, 30 P. 194, 134-35 (1892) (jurisdiction of supreme court exercised coordinately either in department or en banc). The court consisted of a chief justice and six associate justices and could sit in two departments or en banc. The concurrence of three justices was necessary for judgment in department, but the chief justice could order any cause pending before the court to be heard and decided by the court en banc. No judgment of a department was final until 30 days passed, unless approved by the chief justice with the concurrence of two associate justices. CAL. Const. of 1879, art. VI, \$ 2 (repealed 1966).

79. Earlier proponents of dividing the United States Supreme Court found support in the fact that New Jersey's Supreme Court sat in divisions, FIFTH ABA REPORT, supra note 30 , at $40,87-88,374$, but that state's highest court was in fact the Court of Errors and Appeals, N.J. Consr. of 1844 , art. VI, $\$ 1$.

80. See In re Wells, 174 Cal. $467,472-73,163$ P. 657, 659 (1917). 
pellate courts-were created in $1904^{81}$ for that purpose. As the district courts became established the supreme court ceased sitting in panels, and it has sat exclusively en banc for forty-nine years. ${ }^{82}$ The district courts, however, have not functioned merely as appellate divisions of trial courts. They have to an extent taken on the function of the erstwhile supreme court panels, for a decision of a district court binds the whole state until the supreme court holds to the contrary. Regionally located panels of an appellate court create state common law. ${ }^{83}$

\section{B. The History of the Evarts Act}

The two state court systems that most influenced the formation of the federal courts of appeals were New York and Illinois. The leading advocates of the two major proposals for federal intermediate appellate courts-put forward in $1881^{84}$ and $1890,{ }^{85}$ respectively-were Senator Davis of Illinois and Senator Evarts of New York. ${ }^{80}$ The Evarts proposal in 1890 was substantially similar to Davis's 1882 bill, ${ }^{87}$

81. CAL. Const. of 1879 , art. V'I, $\$ 4(1904)$.

82. R. Pound, supra note 31 , at 214 (through 1940); Louisell \& Degnan, Rehearing in American Appellate Courts, 25 F.R.D. 143, 161 n.53 (1956). Until 1966, the supreme court technically could still sit en banc. The new judiciary article of the state constitution, adopted that year, deleted all references to "in department" and "in bank," and four of six associate justices are now required for a quorum. CAL. Const. art. VI, $\$ 2$.

83. The evolution of departmental authority in California has not been prescribed by statute. The division of the supreme court in 1879 provided for transfer of cases between divisions. See CaL. Const. of 1879 , art. VI, $\S 2$. When the district courts of appeal were established in 1903, the supreme court retained power to transfer between those courts and from any one of them to the supreme court. See In re Wells, 174 Cal. 467, 470-72, 163 P. 657, 658-59 (1917); CaL. CoNst. of 1879, art. VI $\$ 4$ (1904). The seminal decision of People v. Davis, 147 Cal. 346, 81 P. 718 (1905), has been construed to mean that a supreme court refusal to transfer a case to itself after decision by the district court of appeal places the high court's "imprimatur" on the decision. District court decisions refused for hearing by the high court are considered to be final not only for the litigants but also for the law. E.g., Housing Auth. v. Peters, 120 Cal. App. 2d 615, 261 P.2d 561, 561 (1953) (decision by district court of appeal in case denied hearing by supreme court binding on state "as settling the law" in absence of later decision by supreme court to contrary); Bridges v. Tefft, 53 Cal. App. 117, 122, 200 P. 71, 74 (1921) (decision by district court of appeal in case denied hearing by supreme court "possesses all the authority of a pronouncement by the Supreme Court itself"); cf. Hruska Hearings, supra note 9, at 910 (Judge James R. Browning, United States Court of Appeals, Ninth Circuit) (federal courts determining California law recognize authority of district courts of appeal).

84. S. 420,47 th Cong., lst Sess., 13 Cong. REc. 69 (1881). Senator Davis introduced the bill into debate on May 1, 1882. 13 CoNG. REC. 3463-66 (1882).

85. H.R. 9014, 5lst Cong., 1st Sess., 21 Cong. ReC. 3402, 3408-09 (1890).

86. H.R. 9014 was introduced by Rep. Rogers of Arkansas, but after passage in the House, 2] Coxs. REc. 3398-3410 (1890), it was referred to the Senate Judiciary Committee, id. at 3425 , where it was stricken after the enacting clause and replaced by the version Senator Evarts had drafted. Id. at 10217-18.

87. See F. Frankfurter \& J. LANdis, supra note 26, at 97.98 (Rogers's bill repeated Davis's proposal; Evarts's bill retained central proposal of Rogers's bill). Indeed, the battle lines of 1890 had been formed in 1882. THRTEenTII AB.1 RepoRT, supra note 30, at 35. 
which was drafted by judicial experts from those two states. Senator Davis noted that his bill originated in a version introduced in 1854 by Senator Douglas of Illinois.88 The Douglas bill provided for annual appellate terms in each circuit. ${ }^{89}$ The Douglas bill resurfaced in 1865, when Senator Harris of New York introduced a similar proposal. ${ }^{00}$ Senator Davis regarded the proposal he offered as the direct offspring of the Douglas-Harris line.91

To justify the federal plan, Senator Davis relied extensively on his state's recently established intermediate appellate structure.92 As a former Associate Justice of the United States Supreme Court he had a special interest in caseload relief, ${ }^{93}$ and he stressed the virtues of intermediate appellate courts in relieving the burden on the Supreme Court. $^{94}$ He dismissed both the potential for conflict in any such system and the significance of conflict in the scheme of state and federal law. ${ }^{95}$ But this attitude may be explained by looking at the Illinois system: with a supreme court "riding circuit,"

(Arr. Dillon, delegate from New York) ("it is the renewal of the old contest"); F. FrankFURTER \& J. LANDIS, supra note 26, at 98 "'The debate upon the bill threshed over old straw.")

88. See 13 Cong. Rec. 3786 (1882) (Sen. Davis); Cong. Globe, 33d Cong., 1st Sess., 1210 (1854) (Sen. Douglas, introducing substitute bill).

89. Conc. Globe, 33d Cong., 1st Sess. 1210 (1854). All the district judges in the circuit were to gather, with one justice of the Supreme Court presiding, and hear all appeals from the district courts in the circuit. See F. Frankfurter \& J. LANDis, supra note 26, at 70 n.54.

90. See 13 Cong. Rrc. 3786 (1882) (Sen. Davis); Cong. Glone, 39th Cong., 1st Sess. 171119 (1865); F. Frankfurter \& J. LANDis, supra note 26, at 71-72.

91. See 13 CoNG. REc. 3786 (1882). Davis noted that his own bill was prepared from the prior proposals by himself and Judge Drummond. Id. They consulted with the New York City Bar Association, one of the oldest and most powerful bar organizations in the country, see N. Brockman, The Politics of the American Bar Association 10 (unpublished thesis on microfilm by Univ. Microfilms, Inc. 1964 (microfilm no. 63-7972)), to create the Davis Bill. See 13 Cons. Rec. 3786 (1882).

92. 13 CoNG. Rec. 3465 (1882) ("The establishment of intermediate courts in Illinois since the constitution of 1870 took effect has been attended with marked success.")

93. W. Kinc, Lincoln's Manager, David Davis 303 (1960).

94. 13 ConG. Rec. 3465 (1882). Another Illinois commentator, however, noted that the diminution in volume of appeals to the Illinois Supreme Court may have resulted from different causes, although he did not claborate. Raymond, supra note 30 , at 78 n.*. A long battle to reform the appellate court structure, see N. GARvEY, supra note 48, at 227 (discussion of longstanding need for reform), finally succeeded in 1962, when independent appellate courts were established. ILL. Const. art. $6, \$ \$ 1,5$ (derived from ILL. Consr. of 1870, art. 6 (1962)).

95. See 13 Cong. Rec. 3466 (1882) (arguing conflict would be no worse than under existing laws). But cf. id. at 3790-91 (Sen. George of Miss.) (attacking Sen. Davis's minimization of conceded potential for conflict).

96. See pp. 1228-29 supra. This was the Illinois solution to the demonstrated tendency of high court judges not to fulfill circuit-riding duties, as in Ohio. 1 Illinois Debates, supra note 48, at 1038 (Mr. Bromwell, pointing out absence of "supreme judge" on circuit in Ohio, in opposition to Mr. Medill's proposal for appellate courts with one supreme judge sitting on each). 
differed from the proposed federal plan. Thus Davis's apparent lack of concern with potential intercircuit conflict may be traced both to his primary interest in relieving the Supreme Court and to his inapposite comparison between the appellate courts of Illinois and the proposed federal courts of appeals. Moreover, it appears that Davis to some extent expected the United States Supreme Court to resolve conflict through certification. ${ }^{97}$ But this has never happened. ${ }^{98}$

Senator Evarts's role eight years later was more complex. He sponsored the Act, but he did not truly support it. He had heard the various reform proposals debated on the state level at the New York constitutional convention of 1867-1868. As a delegate to that convention ${ }^{90}$ and as a member of the committee that drafted the amendment to the judiciary article, ${ }^{100}$ Evarts was close to the compromise that became law in New York. As in 1890 on the federal level, the two reforms discussed in New York in 1867 were, first, to divide the highest court ${ }^{101}$ and, second, to rely on intermediate appellate courts. ${ }^{102}$ And, as in 1890 , the idea of appellate courts, which in New York became a reduced number of appellate divisions, defeated the idea of panel authority in the court of last resort. ${ }^{103}$ There were sound reasons, in a geographically large state, to retain regional appellate courts..$^{104}$ But the need for uniformity went unfilled, as conflict continued.105

Evarts became an eloquent advocate of dividing the federal Supreme Court. ${ }^{106}$ A sharply divided committee of the American Bar Associa-

97. Senator Davis assumed that the general certification power conferred on the courts of appeals would be used if conflict developed, 13 CoNG. REC. 3466 (1882). But certification was not obligatory under his bill. $I d$.

98. For discussion of the Supreme Court's practice in dealing with certified questions, see note 143 infra.

99. 1 N.Y. Constitutional Convention Proceedings, supra note 33, at 18.

100. Id. at 95 (Judiciary Committee).

101. See p. 1227 supra.

102. See id.

103. And yet New York, like other states, intermittently relied on temporary com. missions to relieve the high court's congestion. $R$. Pound, supra note 31, at 201-13; see note 46 supra.

104. 4 N.Y. Constitumonal Convention Proceedings, supra note 33, at 2474; cf. p. 1231 supra (creation of California District Courts of Appeal). Evarts urged compromise between uniformity of law and courts located close to the litigants. 4 N.Y. ConstrrutronaL Convention Proceedings, supra note 33, at 2474.

105. See p. 1228 \& note 47 supra.

106. See 3 Arguments and Spezches of William Maxwell Evarts 331-32 (S. Evarts ed. 1919) [hereinafter cited as ARGUMENTS AND SPEECHES]. Senator Evarts's concern for uniformity of national law preceded the $1882 \mathrm{ABA}$ study: he was one of 14 attorneys to sign the call to found the American Bar Association itself, see Call for $A$ Meeling to Form $A n$ American Bar Associalion, reprinted in The AMERICAN Bar Association, Call for A Conference; Proceedings of Conference; First Meeting of the Association; Officers, Members, ETc. 4 (1878), which was established in part to promote a unitary system of law throughout the country, FifTH ABA REPoRT, supra note 30, at 59 (W.H.H. Russell of Missouri on Evarts's co-founding role and on purposes of ABA). 
tion $(\mathrm{ABA})$, on which Evarts served, presented a report in $1882^{107}$ that advocated circuit courts of appeals, ${ }^{108}$ much like the New York system. Evarts signed the minority report, ${ }^{109}$ which recommended division of the Supreme Court. ${ }^{110} \mathrm{He}$ opposed the proposal for circuit courts of appeals precisely because he foresaw that coordinate appellate courts attached to the trial courts would create conflict that no higher court could manage to resolve. ${ }^{111}$

In 1890, however, Evarts perceived the forces mounting in favor of the Act he had come to sponsor: the American Bar Association, for example, still favored the courts of appeals. ${ }^{112}$ The ABA had always doubted the constitutionality of a divided Supreme Court, ${ }^{113}$ and the passage of a courts of appeals act was its first lobbying effort. ${ }^{114}$ The effort was led by David Dudley Field, ${ }^{115}$ who was as respected a member of the New York bar as Evarts, ${ }^{116}$ but who did not share Evarts's concern for uniformity of law on either the state or federal levels. ${ }^{117}$ The lobbying effort convinced Evarts that the bar in general favored courts of appeals, ${ }^{118}$ and Evarts felt a strong need to accomplish even a second-

107. Majorily Report, supra note 30, at 343-61. The committee divided five to four. See id. at 361 (signers of majority report); id. at 386 (signers of minority report). This division was noted in Senate debate. E.g., 13 CoNG. REc. 3641 (1882) (Sen. Morgan of Ala., referring to "equally" divided committee).

108. Majority Report, supra note 30 , at 351-52.

109. Id. at 386 .

110. Id. at $363-86$.

111. 3 ARguments ANd Speeches, supra note 106, at 330 .

112. Thirteenth ABA Report, sutpia note 30, at 39-40, 338-39; see 21 Cong. Rec. 10306 (1890) (Sen. Evarts: "[T]he preponderance of opinion, judicial and professional, . . . is hostile to the scheme of a division of the Supreme Court into chambers.")

113. Majorily Report, supra note 30, at 353; cf. THIRTEENTH ABA REPoRr, supra note 30 , at 38 (reiterating earlier position). Members of the Supreme Court had also expressed doubts as to the constitutionality of the division of the Supreme Court. 21 Conc. REC. 3403 (1890) (Rep. Culberson, quoting speech of Justice Harlan); Raymond, supra note 30 , at 75 (summarizing article by Hon. William Strong, ex-Associate Justice). Evarts consulted Supreme Court Justices and other federal judges in drafting the 1890 bill. C. Barrows, Willi.M M. Evarts 481 (1941).

114. M. Rutherford, The INfluence of the American Bar Association on Public Orinion and Legislation 131-33 (1937); Radin, The Achievements of the American Bar Association: A Sixty Year Record, 25 . A.B.A.J. 903, 907-10 (1939).

115. Field headed the ABA committees that lobbied for the courts of appeals in 1888 , see Rerort of the Eleventu ANnual Menting of the American Bar Association 125 (1888), and in 1890, see THIRTEENTH AB.1 RePort, supra note 30 , at 95.

116. See generally C. Barrows, supra note 113, at 193; H. Field, The Life of David DUDLEY Field 100-04 (1898) (Ficld's son comparing father favorably to Evarts and to other New York attorneys).

117. Field's concern for codification of the common law was partly caused by a great distrust of judge-made law. See Eighry ABA RePorr, supra note 29, at 353-54 (committee report prepared by Field) (listing objections to court control of law's development). Thus it mattered little to Field if the federal common law conflicted within itself.

118. See note 112 supra.

Evarts presided over a joint hearing of subcommittees of the House and Senate Judiciary Committees before which the Field Committec testified, REPORT of THE SEVENTEETH AN- 
best reform. He called the Act "a practical measure"110 - a passable bill-but he never wavered from the conviction that the better proposal, the divided Supreme Court, had lost. ${ }^{120}$

III. The Courts of Appeals as Panels of a National Court of Appeals

\section{A. The Possibility of Panel Authority: A Proposed New Role for the Courts of Appeals}

Their experience with the New York and Illinois court structures predisposed the drafters of the Evarts Act to conceive of federal courts of appeals as appellate divisions, whose foundation would be the trial court's regional structure. That formulation ignored existing conflict in state court systems whose appellate divisions lacked adequate highcourt supervision. The experience of states like Ohio and Missouri, which had already shifted or were in the process of shifting from the appellate division model to divided supreme courts as the pressures of conflict became too great, ${ }^{121}$ should have provided the drafters with an additional warning. ${ }^{122}$ But they seemingly took no notice.

A different role for intermediate appellate courts began to emerge in California, where the development of intermediate appellate courts as regional panels of a statewide court provides analogical support for the proposition that the federal courts of appeals need not provide uniformity only within discrete venue regions, as they now do. Rather, like

Nual Meeting of the American Bar Association 337 (1894) [hereinafter cited as SevenTEENTH ABA REPORT], and the Field Committee subsequently urged passage of the Evarts Act, see THIRTEENTH ABA RePort, supra note 30 , at 33,36 . The ABA described its role in 1890 as "active, and we have cause to believe . . influential." SEVENTEENTH ABA REPORT, supra at 337.

119. 21 CoNG. REC. 10306 (1890). Emphasizing that the profession would not accept the division of the Supreme Court into chambers, id., Evarts was determined that some reform pass, even if not the one he favored. $I d$.

120. Senator Vest questioned Evarts closely concerning his apparent shift in position, id. at 10308, demanding finally: "I wanted to know if the Senator had changed his opinion," $i d$. Evarts replied, "I never revoked it, even in a newspaper paragraph." Id. Evarts's son, Sherman, maintained that his father never changed his mind, but that he compromised to obtain some reform. 3 ARguments AND SpeEches, supra note 106, at 321 . Evarts's biographer supports that conclusion. C. BARRows, supra note 113, at 480-81:

[Evarts] felt something must be done, but was convinced Congress would never accept the quorum plan [for a divided Supreme Court]. Rather than have no reform, he shifted to the plan of an intermediate court ....

....

... Having previously advocated the quorum plan, he knew its merits and now, curiously enough, found himself refuting those arguments which he had formerly approved.

121. See pp. 1229-31 supra.

122. See 21 CoNG. REc. 10306 (1890) (Sen. Vest) ("If [Evarts] goes into an analogy, so far as the States are concerned, he is trying a precedent which has not been successful in many of the States of the Union.") 
the California courts, they should render decisions as panels of a unitary court of appeals-their decisions should bind the entire nation. ${ }^{123}$

The concept of panel authority is already accepted on the federal level. Not only does the history of the federal courts prior to the passage of the Evarts Act show occasional references to "controlling decisions" of lower federal courts, ${ }^{124}$ but the internal operation of the courts of appeals since 1891 also has evolved in the direction of panel authority. The courts of appeals now sit in panels of three judges, and panel decisions are binding on other panels of the same circuit. ${ }^{125}$ Once established by a panel, the law of the circuit can generally be modified only by the court en banc. ${ }^{126}$ The same conceptual framework should govern relationships among the various courts of appeals. They should

123. Professor Vestal has made a similar proposal, Vestal, supra note 12 , but one that differs significantly from the proposal of this Note. He argues "that a court of appeals could establish the law to be applied in the federal courts and so prevent relitigation by the federal government," id. at 176. But because his proposal is directed toward use of expanded notions of "issue preclusion," or collateral estoppel, to control relitigation by specific litigants (i.e., governmental agencies), see id. at 175-76, it cannot be extended to areas of federal law that do not involve agency litigants. This Note, by contrast, addresses stare decisis rather than res judicata; it seeks to create uniformity in federal law rather than to bind specific parties. Because the Vestal proposal focuses on agency litigants, it can invoke the powerful estoppel doctrines of res judicata, see generally RESTATEMENT (SECOND) OF Judgments $\$ 68$ (Tent. Draft No. I, 1973), without the need to address competing institutional goals. See Vestal, supra note 12 , at 177-79. This Note must address those goals because of its broader scope. See pp. 1240-46 infra. Finally, Vestal's analysis relies on the pre-1891 history of the federal courts, see Vestal, supra note 12, at 130-63, while this Note proposes the nineteenth-century state appellate courts as models for the federal appellate courts. Nevertheless, Vestal's history supports the proposal of this Note, for his examination of "controlling decisions" in the lower federal courts, see id. at 13035 , reveals stare decisis, rather than res judicata, patterns.

124. See Vestal, supra note 12, at 130-35. Vestal deals primarily with patent cases, id. at 130-33, but he does find support in a few nonpatent cases, id. at 133-35.

125. The circuits do vary in their adherence to panel stare decisis, but the doctrine that originates in English common law, see generally R. Cross, PRECEdent IN ENGLish LAw 102-10 (2d ed. 1968) (ratio decidendi of earlier case to be followed by court in subsequent decisions; decisions of full court of appeal no greater in authority for purposes of stare decisis than that of division of court), is generally accepted.

The circuits explicitly recognizing panel stare decisis are the Second, Shattuck v. Hoegl, 523 F.2d 509, 514 n.8 (2d Cir. 1975); but see Note (pt. 1), supra note 36, at 580 \& n.105 (citing Second Circuit cases: two in favor of panel overruling, one dissent in favor, and three opposed to panel overruling); the Third, In re Central R.R., 485 F.2d 208, 210-11 (3d Cir. 1973), cert. denied, 414 U.S. 1131 (1974); the Fourth, Doe v. Charleston Area Medical Center, Inc., 529 F.2d 638, 642 (4th Cir. 1975); the Fifth, Fulford v. Klein, 529 F.2d 377, 379 (5th Cir. 1976), aff'd en banc per curiam, 550 F.2d 342 (5th Cir. 1977); the Sixth, Ashe v. Commissioner, 288 F.2d 345, 347 (6th Cir. 1961), the Ninth, United States v. Jenson, 450 F.2d 1258, 1264 (9th Cir.), cert. denied, 405 U.S. 1043 (197I). Professor Vestal concludes that "court of appeals judges have accepted the idea that they are restricted in their power to decide cases; they accept the view that they must operate within the framework of prior cases decided in the circuit." Vestal, supra note 12, at 161. For an excellent discussion of a difficult panel stare decisis problem confronted by the Second Circuit around 1950, see Note (pt. 1), supra note 36 , at 578-81.

126. See Vestal, supra note 12 , at 161 ; Note (pt. 1), supra note 36 , at $578-81$. 
be treated as panels of a national court, with the role and authority that panels have had on the state ${ }^{127}$ and federal levels.

The increased national role for the courts of appeals is conceptually buttressed by the present transfer power of those courts. The courts of appeals possess both inherent ${ }^{128}$ and statutory ${ }^{129}$ authority to transfer cases from one to another. ${ }^{130}$ The statutory authority, which is limited to appeals from agency action, demonstrates the special solicitude of Congress for the national enforceability of agency regulations. ${ }^{131}$ The courts of appeals themselves have emphasized the national scope of agency-administered law in their statutory transfer of appeals. ${ }^{132}$ In fact, in the transfer of administrative appeals, the law of the transferee circuit applies. ${ }^{133}$ This is consistent with the concept of authoritative panels of a unitary tribunal.

Recent proposals to reform two circuits, moreover, indicate that the federal judiciary might be amenable to panel authority on a national scale. It has been suggested that the Fifth and Ninth Circuits each be subdivided into two, permanent, nine-judge panels. Each panel would sit separately, but each would decide questions of law for the entire circuit. ${ }^{134}$ Indeed, Judge Hufstedler, a Ninth Circuit judge, has compared the proposed restructuring of her circuit to other proposals for "unifying the circuit courts . . . into one unified court sitting in regional panels." 135

\section{B. Implementing the Proposal}

The change proposed by this Note is informed both by the historical antecedents of our present system of judicial organization and by

127. See pp. 1231-32 supra.

128. E.g., AT\&T v. FCC, 519 F.2d 322, 325 (2d Cir. 1975); Eastern Airlines, Inc. v. CAB, 354 F.2d 507, 510 (D.C. Cir. 1965).

129. 28 U.S.C. $\$ 2112(a)(1970)$.

130. There appear to be no cases transferred among the courts of appeals that were not appeals from agency action. This is logical, since nonagency disputes originate in the district courts, which have available 28 U.S.C. $\$ 1404$ (a) (1970) for transfer of cases among themselves. Transfer of agency appeals are not always effected, however, by the use of $\$ 2112$ (a); the statutory power is narrower than the inherent power, and thus the latter is used in cases where the former's limits prevent its application. See, e.g., Natural Resources Defense Council, Inc. v. EPA, 465 F.2d 492, 495-96 (Ist Cir. 1972) (per curiam); Panhandle Eastern Pipe Line Co. v. FPC, 337 F.2d 249, 252 (10th Cir. 1964).

131. See Ball v. NLRB, 299 F.2d 683, 685-87 (4th Cir. 1962).

132. Public Serv. Comm'n v. FPC, 472 F.2d 1270, 1273 (D.C. Cir. 1972).

133. See International Union of United Brewery Workers v. NLRB, 298 F.2d 297, 301

\& n.10 (D.C. Cir. 1961), cert. denied, 369 U.S. 843 (1962) (transferred from 5th Cir.).

134. See, e.g., Hruska Hearings, supra note 9, at 806-26 (Judge John F. Kilkenny, U.S. Court of Appeals, Ninth Circuit), 854-56 (Judge Gus J. Solomon, U.S. District Court, District of Oregon).

135. Id. at 985 . 
modern federal practice, not by the imperatives of agency-administered law. But its application would be particularly appropriate for agencyadministered law, where the law-of-the-circuit rule has been especially manipulated by litigants. ${ }^{136}$ Moreover, as bureaucracies whose final authority is centrally located, federal agencies would be especially receptive to a rule of national panel authority.

Although there is no a priori reason why a three-judge panel of any court of appeals could not decide questions for the entire nation, pragmatic considerations suggest that decisions should have nationally binding effect only if a court of appeals sits en banc. As Judge Friendly has noted, there are practical problems in binding judges by the decisions of judges of coordinate authority. ${ }^{13 \pi}$ Some courts of appeals may prefer conflict of decision to the potential for incorrect decisions by courts that they perceive as less capable of reaching "correct" decisions. ${ }^{138}$ Participation of less than the entire circuit in a decision intended to have nationally binding effect might lack sufficient authority to overcome these problems. Yet the problem of judges being bound by decisions of judges of coordinate authority is not peculiar to the present proposal or to intercircuit transfers; it is present whenever a panel, arbitrarily composed, answers questions for an entire circuit. ${ }^{139}$ Reluctance to accede to another circuit's decision should be overcome by the realization that every court of appeals will have an opportunity to contribute to the law. The analytic relation between three-judge panels as authoritative subdivisions of a circuit and circuits as authoritative subdivisions of a national appellate court would make the proposal all the more acceptable.

Under the proposal, once a court of appeals sitting en banc as a national panel has rendered a decision, a subsequent court of appeals faced with the same issue would be compelled to follow that decision. Even if convened en banc, the second court of appeals would not be

136. See p. 1220 supra.

137. Friendly, Of Voting Blocs, and Cabbages and Kings, 42 U. CIN. L. REv. 673, 676 (1973).

138. This perception is likely given the tendency of one circuit to develop a reputation as "expert" in one area, such as the Second Circuit in securities law or the District of Columbia Circuit in communications law. But in Midwest Television, Inc. v. FCC, 364 F.2d 674 (D.C. Cir. 1966), the District of Columbia Circuit transferred a case that involved the validity of an FCC order concerning community antenna television systems. It did so despite its universally acknowledged expertise in communications law, in order to avoid conflicting decisions.

139. It is the "accident" of panel draw that leads one writer to call en banc decisions more "palatable." Note (pt. 1), supra note 36, at 579, 591. Litigants cannot complain of a "bad" bench without insulting the entire court in that instance. See also Goldman, Conflict and Consensus in the United States Courts of Appeals, 1968 WIs. L. REv. 461, 481-82 (summarizing impact of "bloc voting" on decisions of courts of appeals). 
permitted to overrule the precedent-setting decision; by analogy to intracircuit practice, a panel cannot reverse a prior panel ruling. ${ }^{140}$

It would be permissible, however, for a subsequent court of appeals that is uneasy with the precedent to attach to its order an opinion stating its objections. This "dissent-in-principle" is a familiar technique of judges who feel compelled by stare decisis to follow a ruling with which they disagree. ${ }^{1+1}$ And it would be more than a sounding-off device; it could eventually serve as the basis for a Supreme Court reversal of the original circuit's precedent.

In instances where a subsequent court of appeals feels that a dissentin-principle is inadequate because the rule propounded by the earlier binding decision is dangerously wrong, provision should be made for special use of certification to the Supreme Court.142 In order to certify, a court of appeals should sit en banc, discuss the issue, and provide the Supreme Court with a full development of its reasons for requesting review. To persuade the Court that the question merits its consideration, the request for review should present the Court with a compelling reason why the first decision was clearly erroneous. ${ }^{143}$

\section{Balancing Institutional Needs}

The purpose of this Note's proposal is to reduce conflict of decision in national law. Previous proposals with a similar purpose, such as the National Court of Appeals, have not accommodated other important institutional values; consequently they have been rejected. ${ }^{144}$ In con-

140. See p. 1237 supra.

141. See, e.g., United States v. Topco Assocs., 405 U.S. 596, 612-13 (1972) (Blackmun, J., concurring in result); Goldman, supra note 139, at 476-77 (reporting on interviews with judges).

142. See pp. $1242-45$ infra. Present provisions for certification are contained in 28 U.S.C. $\$ 1254(3)(1970)$ and in SuP. CT. R. 28.

143. Certification is, under the Court's practice, rarely allowed because it is "so exceptional a jurisdiction." Wisniewski v. United States, 353 U.S. 901,902 (1957) (per curiam) (disagreement by one panel of court of appeals with decision of earlier panel insufficient reason to justify certification). Most certified questions answered over the last 35 years involved either jurisdictional or constitutional issues whose determination was blocked by a divided court of appeals. See, e.g., Moody v. Albemarle Paper Co., 417 U.S. 622, 624 (1974) (vote of senior circuit judge cannot be counted in decision to rehear en banc); United States v. Barnett, 376 U.S. 681, 692-700 (1964) (individuals charged with criminal contempt in disobedience of temporary restraining order not entitled to trial by jury); Scripps-Howard Radio, Inc. v. FCC, 316 U.S. 4, 6 (1942) (power of court of appeals to grant stay pending disposition of appeal by FCC). The only exception appears to be Alison v. United States, 344 U.S. 167, 169 (1952) (whether taxpayer allowed to take loss for embezzled funds if funds recovered in subsequent year).

144. For two proposals that have considered competing institutional goals, see Haworth, supra note 7, at 858-59 ("synthesized list of considerations" to be applied in planning judicial reform), and Rosenberg, Planned Flexibility to Meet Changing Needs of the 
trast, the proposal of this Note adequately addresses the institutional values that compete with the need for uniformity.

\section{A. Effect on the Supreme Court: Balancing the Need for Relief Against the Need to Maintain Access and Authority}

To an overwhelming degree, recent proposals that attempt to resolve conflict in federal law have focused on finding partial substitutes for the Supreme Court. ${ }^{115}$ Both the National Court of Appeals and specialized courts of appeals would assume certain functions now performed by the Court. ${ }^{146}$ These courts would relieve the Court of its conflictresolving burden, but they would endanger other values. The primary objection to a National Court of Appeals, for example, is that it would be unconstitutional as a violation of the Article III injunction that there be "one supreme Court."14i Moreover, opponents have emphasized that reducing access to the Supreme Court-now preserved by certiorari-would eliminate the influence of the highest court in important cases. ${ }^{148}$ Some also fear conflict between the Supreme Court and the National Court, and a decline in the authority of both. ${ }^{\mathbf{1 4 9}}$ Finally, commentators point to probable changes in the rest of the federal judicial system that would result from creating a National

Federal Appellate System, 59 CoRNell L. REv. 576, 586-88 (1974) (proposing constraints necessary to success of any plan for appellate reform). Both authors agree that the Supreme Court should retain control of its own docket and that litigants should retain access to the Court, that lower courts should not lose their dignity, and that specialized courts and judges are unwise. Haworth, supra note 7, at 858-59; Rosenberg, supra at 586-88.

145. The proposals for a National Court of Appeals would grant such a court the power to perform functions now solely within the Supreme Court's exercise. See note 7 supra. Other suggestions focus on shrinking jurisdiction, Friendly, Averting the Flood by Lessening the Flow, 59 CoRnel. L. REv. 634, 640, 643-46 (1974), or on multicircuit panels, Leventhal, supra note 1, at 917; Wiener, Federal Regional Courts: $A$ Solution for the Certiorari Dilemma, 49 A.B.A.J. 1169, 1171 (1963).

146. One critic of the Hruska Commission proposal for a National Court of Appeals notes that the provision for transfer jurisdiction would introduce conflicts between the National Court and the Supreme Court, with the latter hesitant to reverse the decision of the former at a later date. Alsup, supra note 7, at 431, 446 (1976). Similarly, specialized courts would withdraw certain legal issues from the broader consideration of the Supreme Court, an "arbiter and mediator of conflicting social interests and demands." Rifkind, supra note 6 , at 426 .

147. U.S. CoNst. art. III, § 1. Professor Charles Black has warned: "A court that can finally determine, for the whole nation, questions over the whole range of federal law, without the possibility of further review, is a 'Supreme Court' in everything but name, and the Constitution provides for one Supreme Court, quite as clearly as it provides for one President." Black, supra note 7, at 885 . Accord, Gressman, The Constitution v. The Freund Report, 41 GEo. WAsH. L. REv. 951,962 (1973).

148. Black, supra note 7 , at 888 ; see note 7 supra.

149. Alsup, supra note 7, at 446; Feinberg, $A$ National Court of Appeals?, 42 BrookLris L. REv. 611, 616.17 (1976). 
Court of Appeals, changes that could endanger the influence of the courts of appeals. ${ }^{150}$

Authority and access are characteristics that the Supreme Court should retain. Both emanate in part from the Court's discretionary review of cases. ${ }^{151}$ The procedure suggested by this Note would provide uniformity without significantly diminishing the Court's discretionary review. On one level, to be sure, the mechanism would restrict access to the Supreme Court. Certification by a discontented court of appeals is likely, for three reasons, to be used infrequently. First, knowing that no nationally binding decision can result, the court considering certification would hesitate to undergo the inconvenience of the en banc procedure. ${ }^{152}$ The step would not appear worthwhile except in cases of extreme disagreement. Second, the act of certification would expose the certifying court of appeals to two forms of scrutiny from the Supreme Court: the Court would examine not only the certifying court's view of the merits of the decision but also its view of the importance of the issue involved. ${ }^{1 \overline{3} 3}$ Third, although one may fear that if Circuit $A$ certifies a Circuit $B$ precedent, Circuit $B$ will retaliate by certifying a Circuit $A$ precedent, that fear should be mitigated by experience with current internal circuit operations. It is not common practice for panels of courts of appeals to indulge in retaliation by attempts to undermine prior panel decisions; in fact, panel stare decisis is rigidly maintained in several circuits. ${ }^{154}$

But though certification would be infrequent, access would not be severely limited. Whether or not the Court ever decides such issues on the merits, potential Supreme Court review is a valuable legal fiction whose presence permeates our judicial system. ${ }^{155}$ Moreover, the Court

150. Chief Judge Kaufman, among others in the federal judiciary, has warned of "the diminution of authority and prestige of the courts of appeals," in his opposition to the National Court of Appeals. U.S. Commission on Revision of The Federal Appellate Court Structure, Hearings Second Phase, 1974-75, at 1330, 1333; Feinberg, supra note 149, at 615. 151. Leventhal, supra note 1 , at 887-88; see note 7 supra.

152. See Galella v. Onassis, 487 F.2d 986, 1004-05 (2d Cir. 1973) (practice of selectivity in decision to go en banc); Hruska Hearings, supra note 9, at 366, 889, 985 (Circuit Judges Wisdom, Duniway \& Hufstedler) (noting inconvenience of en banc procedure); Note (pt. 1), supra note 36 , at $574-77$.

153. See Wisniewski v. United States, 353 U.S. 901, 902 (1957) (per curiam) (dismissing certificate: "It is . . . the task of a Court of Appeals to decide all properly presented cases coming before it, except in ... rare instances ....."); note 143 supra.

154. Although this is especially true in the Fifth Circuit, see Atlantis Dev. Corp. v. United States, 379 F.2d 818, 828 (5th Cir. 1967) (panel decision may only be overturned by Court en banc or when there exists intervening Supreme Court decision), most circuits have supported panel stare decisis, see note 125 supra.

155. The Freund Report's national court, Professor Black notes, "could do just what I have said only a 'Supreme Court' can do, in any case of intercircuit conflict, whatever the question might be." Black, supra note 7, at 885. The Hruska Commission's proposal also received criticism for forcing the Supreme Court "to share with the National 
alone would retain the power to decide that the particular issue is in need of its analysis, for under this Note's proposal review by certiorari would remain available. It is possible that the Court might hesitate to review cases covered by a nationally binding decision, because there may be only one decision-that of the first court of appeals-to consult on the issue, rather than the usual range of conflicting opinions. But with the new rule in force, the Court would still be free to follow its present practice of justifying the granting of certiorari on grounds of serious error or the need for a strong policy decision..$^{156}$

\section{B. The Effect on the Courts of Appeals: Forum-Shopping and Ripeness}

\section{Ending the Shopping Spree}

An aim of this proposal is to curtail relitigation and forum-shopping by agencies. Forum-shopping is common among federal agencies and occurs in stages: in cases of first impression an agency may attempt to select a circuit that will rule in its favor; ${ }^{157}$ when an issue has been decided in one circuit, the agency may continue to shop for a favorable forum, in hopes either of reinforcing a favorable decision or of weakening an unfavorable one. ${ }^{158}$ These opportunities would diminish under the proposal of this Note. In the first case, agencies might still shop for a favorable forum. But once a court of appeals sits en banc and creates a national precedent, the proposed rule would eliminate the opportunity to locate a forum on the other side of the issue. Some selection by agencies might still occur, but agencies would be forced to confine their shopping to a search for a forum willing to distinguish the more recent case from the national precedent or willing to certify to the Supreme Court. ${ }^{150}$

Court of Appeals the power to decide important constitutional questions without any effective review by the Supreme Court, a result that would diminish the authority and position of the Supreme Court in our political system." Alsup, supra note 7 , at 448 .

Arguments against proposed specialized courts have warned that such courts would either "repel the ablest judges, or foster a narrow, slit-viewed approach. Moreover, new judicial posts should be furnished safeguards against efforts of special interests to control the process of selecting the judges." Rosenberg, supra note 144, at 588. Judge Rifkind opposed a specialized court for patent litigation out of concern for the area of law itself, which he felt would become isolated from "exposure to the self-correcting forces of the law." Rifkind, supra note 6 , at 425 .

156. See Gressman, Mruch Ado About Certiorari, 52 GEo. L.J. 742, 743 (1964).

157. Carrington, supra note 1 , at 598 .

158. See HRUSKA Commission REPORT, supra note 2, at 21-27; Leventhal, supra note 1, at 904-05; Vestal, supra note 12, at 123-27.

159. One reason an agency forum-shops, of course, is because it perceives the decision of one or more courts of appeals to be "incorrect." Indeed, the opportunity for agencies to retrieve misguided decisions of courts of appeals by relitigating in another circuit might 


\section{Ripeness}

The proposal of this Note would eliminate intercircuit conflict. Uniformity would be achieved. But conflict can be seen as a positive influence in some circumstances. One benefit of conflicting decisions is the development of thought in specific areas of law. ${ }^{160}$ If forum-shopping and relitigation were curtailed, there would be less potential for several fully reasoned decisions and thus less chance for fully developed principles of law. The Supreme Court, through the ripeness doctrine as applied to issues (not to specific cases), ${ }^{161}$ has refused to consider cases whose questions lack the requisite legal development. ${ }^{102} \mathrm{~A}$ very real danger under the proposed rule is that, with only one complete analysis of an issue by a court of appeals, the Supreme Court would be hindered in its subsequent review of that issue on certification or on litigant certiorari. Uniformity would then become a tyrant in its own right; in instances where the Court would otherwise grant review, it might hesitate when confronted with a paucity of detailed lower court analysis.

Although lack of ripeness might present problems under certain circumstances, it does not do so in the areas of law most appropriately subject to the proposal of this Note-agency-administered law. Dean Griswold has noted that tax and labor law involve detailed, daily

be viewed as a major virtue of the law of the circuit. But the proposal of this Note may provide some compensation for loss of this opportunity. As one writer has noted, the en banc decision of a court of appeals involves the contribution of several minds, which may limit the chances for error. Note (pt. 1), supra note $\mathbf{3 6}$, at $\mathbf{5 8 9} 9$. Moreover, a court sitting en banc may perceive itself as speaking with more authority and thus as assuming more responsibility for correctness. Id. at 589-90.

160. See HRUSKa CoMmission RePort, supra note 2, at 14 ("There are some issues as to which 'successive consideration by several courts, each reevaluating and building upon the preceding decisions' will improve the quality of adjudication."); Friendly, Averting the Flood by Lessening the Flow, 59 CoRnel L. REv. 634, 654-55 (1974); Leventhal, supra note 1, at 908-09 (advantages of "percolation" should be preserved).

161. See A. BICKeL, THE LEAST DANGerous Branch 143 (1962) (noting twofold problem in Times Film Corp. v. City of Chicago, 365 U.S. 43 (1961): suit's ripeness for review and issue's ripeness for review).

162. Professor Bickel analyzed ripeness in the context of Poe v. Ullman, 367 U.S. 497 (1961), whose "issue itself was not ripe at all." A. BICKEL, supra note 161, at 143. The Court was asked to adjudicate an issue with which the state had not initially dealt. Bickel warned that in such a situation "judicial review would sap the quality of the political process, because it would tend, much more than normally, to be exercising initial rather than reviewing judgment." Id. at 155. See Colorado Springs Amusements, Ltd. v. Rizzo, 428 U.S. 913, 918 (1976) (Brennan, J., dissenting from denial of certiorari) (Court should obtain "views of state and lower federal courts on important issues"); Maryland $v$. Baltimore Radio Show, Inc., 338 U.S. 912, 918 (1950) (denying certiorari) (separate opinion of Frankfurther, J.) ("It may be desirable to have different aspects of an issue further illumined by the lower courts. Wise adjudication has its own time for ripening."); $c f$. Vestal, supra note 12, at 178 \& $\mathrm{n} .306$ (quoting Ballimore Radio) (distinguishing need for ripeness in constitutional and nonconstitutional cases). 
interpretations of technical regulations or complicated fact situations that do not require ripeness so much as uniformity and quick decision. ${ }^{103}$ His observation is equally apt for much of agency-administered law.

Further, it is doubtful that conflict always creates ripeness. The proponents of conflict favor it because they believe that disagreement allows ideas to progress dialectically and leads therefore to a proper conclusion to a controversy. ${ }^{164}$ It is not at all clear, however, that conflict consistently produces such synthesis. In regulatory law-much concerned, as it is, with detail-conflict is likely to create confusion among lawyers, clients, and the judiciary.

Even if issue ripeness is deemed necessary, however, there are several sources that would provide it. The need for ripeness is nearly always associated with court-created analyses. ${ }^{165}$ Yet agencies themselves, as litigants with a special interest in one area, can provide the necessary discussion. They continually deal with factual variations within a specific issue. The Internal Revenue Service, for example, supplies revenue rulings for many individuals on closely related questions. And the National Labor Relations Board's regional counsel may issue many orders that involve similar legal queries. The agencies themselves are constantly developing a range of factual situations that provides a full background against which the legal issues can be considered. Moreover, the full discussion available when a court of appeals sits en banc may well provide a substitute for ripeness.

Once the national precedent is set, other courts of appeals would follow it. This would indeed discourage analysis of the underlying issues. But discussion may not cease entirely; attempts to discern factual distinctions between new cases and the case establishing the binding precedent might serve to sharpen issues.

If a court of appeals determines that a case before it cannot be distinguished from the precedent-setting case, the court's decision should be a cursory order citing the prior decision. That is the object of the proposed rule. But dissents-in-principle would still be available. Courts of appeals that have chosen to follow the decisions of other courts of appeals in specific areas ${ }^{166}$ have nevertheless occasionally explored the opposing arguments in detail. ${ }^{167}$ This option would be

163. Hruska Hearings, supra note 9, at 21.

164. See Friendly, supra note 145, at 655; Leventhal, supra note 1, at 908-09.

165. See Hruska Hearings, supra note 9, at 21 (Dean Griswold).

166. The cases noted by Professor Vestal for the most part involve tax and patent matters. See Vestal, supra note 12, at 130-60.

167. See generally id. 
available to courts of appeals that disagree with nationally binding precedents ${ }^{168}$ but not to the extent necessary to inspire certification. In fact, the encouragement of the practice could curb the temptation to certify, especially if a court realizes that its views will be of value to the Supreme Court in the event that certiorari is granted or certification is accepted in a subsequent case. Finally, of course, if certification is brought, there would be available to the Supreme Court the en banc opinions of the two courts of appeals. It is unlikely that an issue discussed by so many circuit judges would not be ripe for decision by the Supreme Court.

\section{Conclusion}

Through its power to create inferior federal courts, ${ }^{160}$ Congress could legislate the changes necessary to formalize the courts of appeals as panels of a national court of appeals. ${ }^{170}$ This Note proposes that the resulting panel authority be exercised by the courts of appeals en banc where intercircuit conflict has undermined the uniform impact of national law. So long as competing interests, such as issue ripeness and access to and authority of the Supreme Court, are accommodated, uniformity in federal law can be realized without the sacrifice of those other institutional goals. The proposal put forward in this Note, if implemented, would strike the proper balance.

168. The Tax Court has in fact expressed its intention to foster uniformity by "explaining why we agree or disagree with the precedent that we feel constrained to follow." Jack E. Golsen, 54 T.C. 742, 757 (1970). It is doubtful that uniformity has been a benefit of such explanations, since the Tax Court adheres to the law of the circuit. But issue ripeness certainly is achieved by such dissents-in-principle. And even assents, if accompanied by full reasoning, are helpful in delineating the issue.

169. U.S. Consr. art. $1, \S 8$, cl. 9 .

170. It may be argued that Congress would be barred by the principle of separation of powers from legislating in an area so fundamentally judicial as rules for stare decisis. Cf. Frankfurter \& Landis, Power of Congress over Procedure in Criminal Contempts in "Inferior" Federal Courts-A Study in Separation of Powers, 37 HARv. L. Rev. 1010, 1020 \& n.56 (1924) ("Independence of judgment must be left to the court in cases where it may decide. . . . [Congress] may not coerce the judgment of courts by the imposition of an arbitrary rule." (footnote omitted) (citing United States v. Klein, 80 U.S. (13 Wall.) 128, $147(1871))$ ). But as Frankfurter and Landis noted, Congress may control "the rules for decision in different classes of cases," id. at 1019 (footnote omitted). See id. at 1019-20; cf. Erie R.R. v. Tompkins, 304 U.S. 64, 79-80 (1938) (Federal Judiciary Act of 1789, $\$ 34$, ch. 20, 1 Stat. 92 (current version at 28 U.S.C. $\$ 1652$ (1970)), not unconstitutional).

It is, moreover, appropriate that Congress make any change that is made. Although the Supreme Court arguably could establish this Note's proposal-at least as to civil casesunder the Rules Enabling Act, 28 U.S.C. $\$ 2072$ (1970), such a major change in the perception of the courts of appeals-from distinct courts to panels of a national courtshould come from the legislature, even though no change in court personnel or jurisdiction would be required. 